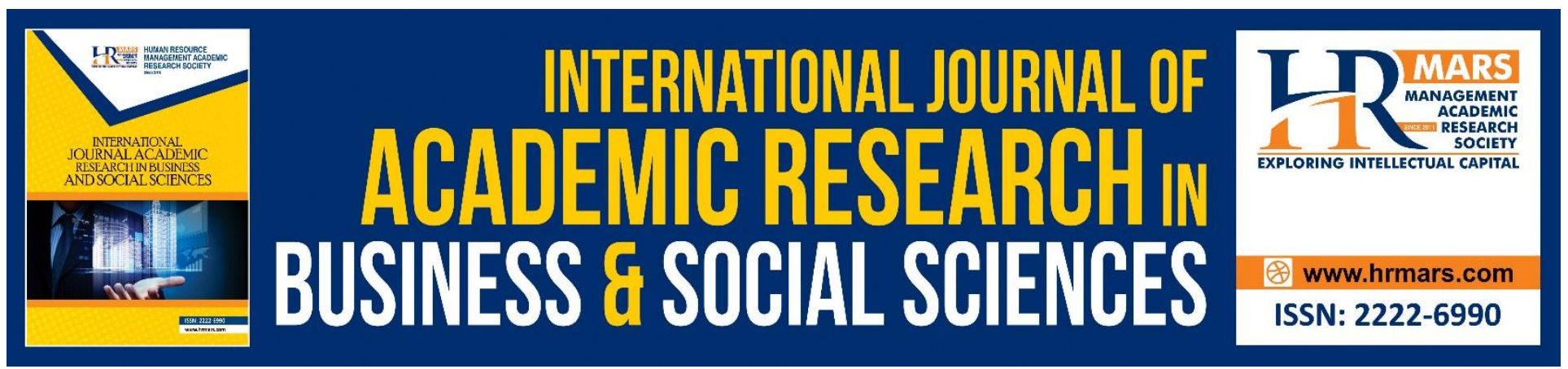

\title{
Conceptual Framework of Bank's Financial Stability, Governance Mechanisms, Regulation and Risk Management in the Kingdom of Saudi Arabia
}

Shroq Ayedh Althubaiti, Siti Zaleha Abdul Rasid

To Link this Article: http://dx.doi.org/10.6007/IJARBSS/v10-i3/7022

DOI:10.6007/IJARBSS/v10-i3/7022

Received: 19 January 2020, Revised: 01 February 2020, Accepted: 22 February 2020

Published Online: 23 March 2020

In-Text Citation: (Althubaiti \& Rasid, 2020)

To Cite this Article: Althubaiti, S. A., \& Rasid, S. S. A. (2020). Conceptual Framework of Bank's Financial Stability, Governance Mechanisms, Regulation and Risk Management in the Kingdom of Saudi Arabia. International Journal of Academic Research in Business and Social Sciences, 10(3), 54-76.

Copyright: (c) 2020 The Author(s)

Published by Human Resource Management Academic Research Society (www.hrmars.com)

This article is published under the Creative Commons Attribution (CC BY 4.0) license. Anyone may reproduce, distribute, translate and create derivative works of this article (for both commercial and non-commercial purposes), subject to full attribution to the original publication and authors. The full terms of this license may be seen

at: http://creativecommons.org/licences/by/4.0/legalcode

Vol. 10, No. 3, 2020, Pg. $54-76$

http://hrmars.com/index.php/pages/detail/IJARBSS

JOURNAL HOMEPAGE

Full Terms \& Conditions of access and use can be found at http://hrmars.com/index.php/pages/detail/publication-ethics 


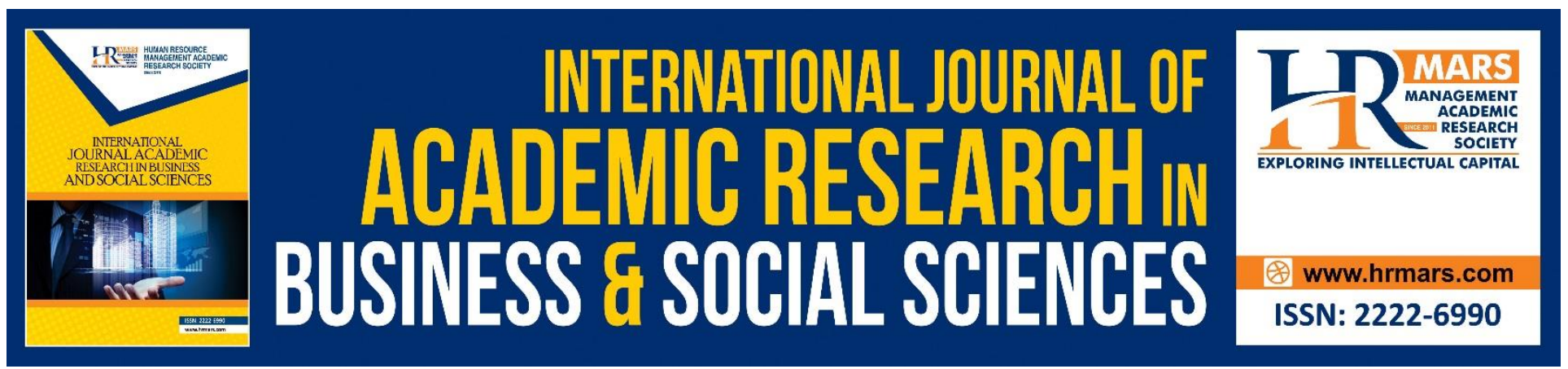

\title{
Conceptual Framework of Bank's Financial Stability, Governance Mechanisms, Regulation and Risk Management in the Kingdom of Saudi Arabia
}

\author{
Shroq Ayedh Althubaiti, Siti Zaleha Abdul Rasid \\ International Buseness School, University of Teknologi Malaysia \\ Johor, Malaysia \\ Email: Saealthubaiti2@graduate.utm.my, szaleha.kl@utm.my
}

\begin{abstract}
Risk-taking is part and parcel of several organizations. In practical sense, risk management assisted the organization in meeting their underline objectives in spite of associated risks. To achieve this, financial institutions employs risk policies as well as frameworks that is suitable for their business operations. This study presents financial performance enhancement model for banking industry in the Kingdom of Saudi Arabia. This study aim to review impact of regulation on risk management and explore effectiveness of the role of board directors between capital adequacy and risk management. This study evaluates board director's effectiveness based on five characteristics; size, independence, meeting, age diversity, and board committee.
\end{abstract}

Keywords: Operational Risk, Governance Mechanisms, Liquidity Risk, Bank Regulation, Risk Management, Risk, Bank Capital Requirement, Credit Risk, Loan to Deposit.

\section{Introduction}

Financial sectors across the globe were significantly affected during 1997 Asian and 2008 global financial crisis. As a result, countries have since focused their attention on the enhancement of regulations that will improve their economies in general and protect the banking sector against the recurrence of such situations. Today, the regulating policy framework for the banking sectors has becoming more stringent (Paun et al., 2014). For example, Basel Committee for Banking Supervision issued new global regulations, the Basel III (Ivashina \& Scharfstein, 2010). Basel III established a wideranging set of reform measures by amending the weaknesses in Basel II. It was noted from the previous studies that lax capital requirements significantly impacted bank level risks (Ayadi \& Boujelbene, 2014). The ratio of capital adequacy quantifies available capital of a bank as a proportion of a bank's risk-weighted credit exposures (Furlong \& Keeley, 1989). Kashyap et al. (2002) also noted that adequacy of capital verifies the lowest amount of capital requirement of an economic capital limit. Adequate capital ensures that banks have sufficient cushion to take in practical losses before losing the depositors' funds in insolvency. In addition, it guarantees financial system efficacy and 
stability by diminishing the associated risk of banks becoming bankrupt (Blum, 1999). Banks in Saudi Arabia adhere to Basel III (Elbadry, 2018). Imperatively, Saudi Arabian Monetary Authority (SAMA) is accountable for warranting dependability and reliability of the banking system and its effectiveness in undertaking its roles for the service of the nation and stakeholders (Ronall, 1967). In line with recent and other developments over the recent past, the regulatory agency, SAMA, has formulated and implemented measures, building on the existing international and local regulatory framework to foster compliance within the banking sector.

Another focus area under the Basel III regulatory framework, are the risks associated with the utilization of held deposits to advance loans. Basel III set the ratio of loan to deposit (LTD) to maximum of $85 \%$ for banks. Working with these guidelines, SAMA decided to increase LTD ratio to a maximum of 90\% since February 14, 2016 (International Monetary Fund, 2017). As reported in the studies of Rengasamy (2014); Elbadry (2018), an increase in the LTD in a particular year will result in increased liquidity risk and credit risk in the subsequent year. Based on the empirical evidence gathered in the study, Elbadry (2018) found a significant negative impact of LTD on liquidity risk of Saudi banks. According to International Monetary Fund (2017); Darwish, \& Abdeldayem (2019), it was reported the Saudi economy faced another risk related to its capability to implement the government reform agenda in the non-oil sectors over the longer term. While different studies have been conducted over the years, there is insufficient research investigating the impact of SAMA's decisions on Saudi banks' risk exposure in line with the current policy framework. Hence, this proposed study seeks to bridge the research gap by investigating the effect of SAMA's new decision; to increase LTD to $90 \%$, on the Saudi banks' risk. The findings of the study may enable Saudi authorities to evaluate the impact of SAMA's new rules especially on LTD ratio and the associated risks.

Other than the regulatory and policy framework in place, there are other aspects of a business, which may have an impact on the risk exposure and operational efficiency of banks, more particularly, the corporate governance structure of the business. The efficacy of the management team as well as ownership structure together with other corporate governance instruments is to ensure that suitable risk taking (Fama, 1980; Ayadi \& Boujelbene, 2014). Studies have established that approaches to managing risk and the management structure in the context financial institutions are substantially important in guaranteeing the stability of an economy (Saunders et al, 1990). Corporate governance designates the way corporations are controlled as well as those in-charge of the direction of firms. This is because it deals with the relationship among the accountability of the organization's stakeholders, processes, guidelines, practices, standards, regulations, and principles that have might impact the direction and control of the organization (Conyon, 1997; Darwish, 2015). Efficacious corporate governance diminishes the control that is handed to managers by stakeholders and creditors and thereby increasing the chance that managers make an investment that increases shareholder value (Morck et al., 1988). Efficient corporate governance performance is therefore crucial in the banking system since commercial banking operations are not as transparent as other firms (Spong \& Sullivan, 2007). Significant impact of the board composition on organization has been documented in earlier studies (Dulewicz \& Herbert, 2004; Mohamed et al., 2013). More specifically, several studies reveal that board composition with respect to the amount of external directors versus 
INTERNATIONAL JOURNAL OF ACADEMIC RESEARCH IN BUSINESS AND SOCIAL SCIENCES

Vol. 10, No. 3, March, 2020, E-ISSN: 2222-6990 @ 2020 HRMARS

internal directors gives rise to better performance due to improved monitoring as described in the agency theory (Fama, 1980; Demsetz \& Lehn, 1985). In agreement, Weisbach (1988) demonstrated existence of direct relationship between total amount of external directors among organization management board and organization performance.

Other aspects of board characteristics and their impact on corporate governance have been evaluated in other studies. De Vita and Luo (2018) studied the interaction between board directors and bank regulation and used the same as the basis for examining banks associated risk. It seems the study of De Vita and Luo (2018) is among the rare studies that examined this issue empirically. However, it is noticeable that their study only considers three board characteristics, which may be inadequate considering the fact that there are other board characteristics that may have an impact on the risk exposure of banks. Thus, this study will extend the studies of Laeven and Levine (2009); De Vita and Luo (2018) by seeking to bridge the empirical gap on various other aspects or elements not studied in the previous studies. Consequently, the overall purpose of this research is to examine the contribution of capital regulation and board directors' effectiveness towards regulators' motivation and effectiveness. The study used panel data obtained from Saudi Arabia's database having a total of 26 banks in the proportion of 12: 14 for domestic and foreign banks respectively. The period of study ranges from 2010 to 2018.

\section{Literature Review \\ BASEL Accord and BASEL Development \\ BASEL I}

The first agreement was made as far back as the late 1980s. These agreements were made because banks, regulators and other institutions throughout the world were worried about bank-level and system-wide risks (Basle, 1988).One of the requirements that stood out from Basel I were the stipulations that it was banks' responsibility is to maintain certain capital level (Tier one \& Tier two) at least 8 percent when measured against RWA (risk-weighted assets) ( Basle, 1988; Jokipii, 2009; Ayadi \& Boujelbene, 2014).The early 1990s saw banks diversifying their operations and investing in securities. Some regulators thought that this increased banks' risk exposure (Stiroh \& Rumble, 2003). These concerns led to the Basel Committee suggesting that banks ought to follow either the Internal Management Approach (IMA) or the Standardized Measurement Approach (SMA) to maintain funds against price risk (Basel Committee on Banking Supervision, 2005). However, some critics faulted the stipulations of the accord saying it was too rigid. The argument was that it used the same approach to fit all situations which do not consider the risk sensitivity in approximating bank capital requirements into account (Ojo, 2009; Zicchino, 2005). The concerns raised necessitated a review of the BASEL I accord.

\section{BASEL II}

The discontent and the challenges associated with BASEL I precipitated further consultations among different stakeholders. After many meetings, discussions and several draft documents, the Basel Banking Committee not only agreed but also signed a new and broader framework for regulating the banking sector. As reported in the 2006 Banking Supervision document from the Basel Committee that apart from capital requirements, the new framework covered another two equally important 
INTERNATIONAL JOURNAL OF ACADEMIC RESEARCH IN BUSINESS AND SOCIAL SCIENCES Vol. 10, No. 3, March, 2020, E-ISSN: 2222-6990 @ 2020 HRMARS

guiding principles; market discipline and supervisory review (Hudson, 2003; Decamps et al., 2004; Tschemernjak, 2004). Besides the $8 \%$ minimum adequacy requirement, the RWA now factored in another three kinds of associated risks such as risk related to provision of credit, risk related to nature of the market and risk related to operation activities. However, the standardized internal rating method and advanced internal rating method are the two new methods suggested by new accord to compute capital requirement for risk related to operation as well as credit (Heid, 2007; Hudson, 2003). After passing the accord, the EU rapidly employed the foundation, standardized methods of estimation and advanced methods by 2008 (Dierick et al., 2005). By the time the 2008 global financial crisis occurred, many banks around the world had already adopted the Basel II requirements and were estimating all three type risks utilizing a standardized approach (Jayadev, 2013). However, some analysts noted weaknesses in the Basel II accord, pointing to the fact that the accord failed to account for important factors which became more evident in the 2008 global economic crisis (Fratianni \& Marchionne, 2009; Acharya et al,., 2011). Furthermore, by adopting VaR (Value at Risk) models in compliance with Basel II, banks usually use trading book exposures to maintain capital requirements which included derivative products, bonds and other assets that many consider to be extremely risky, which was among the reasons behind the global financial crisis (Tschemernjak, 2004; Jorion, 2007). The third flaw is that the Basel II accord did not have an explicit rule or requirement that regulated leverage (Svilenova, 2011). Accordingly, as was the case with BASEL I, the flaws in BASEL II necessitated a further review, with an objective of improvements to improve banking regulatory policies and framework.

\section{BASEL III}

Premised on a review of BASEL II, with an objective of improving the regulatory framework, BASEL III was born. The Banking Committee for Basel recently updated its guidance on banking regulations in response to the 2008 crisis that strives to maintain larger reserves with strong quality of capital (Ayadi \& Boujelbene, 2014).

The Basel III accord has several key agendas put in place to prevent recurrence of financial-related crises. The purpose is eliminate recurrence financial crisis through the proposed agenda enumerated below:

- $\quad$ Encouraging transparency and disclosure.

- $\quad$ Surcharging systematically important financial institutions (SIFIs).

- $\quad$ Use of a minimum leverage ratio which is not risk related.

- $\quad$ Enhancing and improving global capital framework through better quality capital and by reducing the effect of pro-cyclical risks via counter-cyclical mitigation measures and capital conversion.

- $\quad$ Using Liquidity Coverage Ratio and None-stable Funding Ratio to tightening liquidity standard in either short-term or long-term.

These agendas plus other components agreed to by the parties that signed the Basel accord essentially formed a new framework that led to radical changes in the way banks were regulated across the globe (Ozkan \& Iqbal, 2015). At the policy level, the groundwork had been laid for improved regulation of the banking sector. To augment the policy and regulatory framework, other measures of managing risks have been used in the industry. 
INTERNATIONAL JOURNAL OF ACADEMIC RESEARCH IN BUSINESS AND SOCIAL SCIENCES

Vol. 10, No. 3, March, 2020, E-ISSN: 2222-6990 @ 2020 HRMARS

\section{The Impact of Financial Stability Indicator on Risk Management}

Financial stability indicators are important tools in managing the banks related risk. In reference to the study by Saif-Alyousfi et al. (2017), profitability of a bank is important and provides insights into the stability of a bank and different risks. The focus of Saif-Alyousfi et al. (2017) on the banking industry in the Kingdom of Saudi Arabia, and their findings established a direct link between profitability of the banks and non-performing loans. Accordingly, as enumerated by Saif-Alyousfi et al. (2017), low profitability implies that the bank is more susceptible to different risks, namely; liquidity, credit, and legal risks due to violations of the allowed amount of net deposits or capital to be loaned out to customers. In another related study, Zehri and Ben Mbarek (2016) investigated the causes of financial distress in Saudi Arabia's banking industry using financial performance ratios such as financial ratios, efficiency ratios as well as risk related accounting ratios. The authors obtained financial ratio data of 11 of the largest banks from Saudi Arabia in the proportion 4:7 for Islamic banks and conventional banks respectively. Their period of study ranged from 2005 to 2014 financial years. The outcomes of the study demonstrated that the banks adhering to the Islamic financial system were better suited in terms of risk management and positioned to resist financial crisis relative to conventional banks because they were more compliant.

In another study, Abdelrahim (2013); Khalid, Islam \& Ahmed (2019); Alzgool (2019) investigated the determining factors, challenges and developing ways of managing credit related risk in the Saudi Arabia banks using the CAMEL model for the analysis and to quantify credit risk management impact on bank performance. The outcomes of the study revealed strong as well as significant correlation between liquidity level and effectiveness of credit risk management of the Saudi Arabia banks. Elbadry (2018) studied other aspects of managing risk, and the study investigated the effect of financial stability on Saudi Banks thorough risk management approaches. In particular, the author employed dissimilar ordinary least square models in order to examine the financial statements from 12 different banks in Saudi Arabia over the period of 2011 to 2014 financial years. He identified a range of measures, including provisions, leverage, ratio of loans to deposits, deposit and asset utilization ratios, and other parameters that collectively intimate that financial stability measured from different perspectives, is indicative of lower risk-taking behavior, and subsequently, lower risk and high stability of the banks. Financial stability of a bank, measured using different ratios therefore, is a key indicator of the risk exposure of a bank, as well as its stability, with the banks in a strong financial position being more stable, while those facing financial instability, as measured using profitability and other discussed ratios, could be considered as being more susceptible to the failure.

\section{Corporate Governance Mechanisms Impact}

A further scrutiny of the measures aimed at fostering banking institutions stability necessitates an indepth evaluation and critique of the corporate governance practices and strategies, which augment the regulatory and policy framework and financial stability measures in assessing risk exposure, particularly in the banking sector. Indeed, there are global recommendation of corporate governance as an appropriate risk management tool for banking sector that have been documented. Indeed, recognizing the importance of corporate governance, the 2010 Basel Committee for Banking Supervision proposed different principles aimed at bolstering the usage of the tool in the banking 
INTERNATIONAL JOURNAL OF ACADEMIC RESEARCH IN BUSINESS AND SOCIAL SCIENCES Vol. 10, No. 3, March, 2020, E-ISSN: 2222-6990 @ 2020 HRMARS

sector (Peni \& Vähämaa, 2012; Basel Committee on Banking Supervision, 2015). The board of directors, which is one of the key tools of corporate governance, provides guidelines for risk governance; evaluation and supervision of bank processes; including the regulation of the selection of board directors' members and provision of guidelines for the implementation of executive reward systems. Boards of directors are made up of individuals that represent the shareholders, and at all times they ensure that management actions and business operations are not conflicting with the interests of the business owners, the shareholders (Chouaibi et al., 2009; Berger et al., 2016). In agreement, Pathan (2009) established that strong boards, including competent individuals, and risk management committees, as a part of the boards of directors, discharging their oversight role ensures that management action meet the legal requirements and promotes moral and ethics.

Other than boards and board characteristics and responsibilities, there are other elements or mechanisms of strong corporate governance, which according to (Peni \& Vähämaa (2012) address the agency problem, or the issues that may emanate from the relationship between the management and the owners (shareholders, management, and stakeholders). Key among these additional considerations under corporate governance are disclosures and reporting (Nguyen, 2011; AlMaghzom et al., 2016), ethical code of conduct (Laeven \& Levine, 2009), whistleblowing policies, executive compensation policies, benchmarking and standardization, and adherence to the laws of the land (John et al., 2008; Berger et al., 2016). These findings and arguments were evident in Saudi Arabia, where a study by Al-Maghzom et al. (2016) ascertained that banks that were committed to financial reporting and disclosure, are less susceptible to risks.

In general, corporate governance indices have received several contribution from researchers (Gompers et al., 2003; Zelenyuk \& Zheka, 2006; Bhagat et al., 2008; Bebchuk et al., 2009), which demonstrates that there still are several other approaches to investigating corporate governance. For example, some previous studies were able to choose between two ways (individual or indices) when they examined the variables (Ntim, 2009). When using only individual approach, which focuses only on one board members characteristics, the finding might be limited. On the other hand, if the study uses only indices, the findings are limited to the group level. Different from previous studies (Gompers et al., 2003; Pathan, 2009; De Vita \& Luo, 2018), the effect of each component of board effectiveness index is also examined using an individual approach. With this approach, individual impacts may be quantify for making comparison between previous findings and current findings may provide relevant information for more stringent decision-making.

\section{Board of Directors and Board Characteristics}

As enumerated above, one of the key elements of corporate governance, and therefore an important factor in the management of risks in the banking industry, is the board of directors. Barnhart et al. (1994); Shleifer and Vishny (1997) debated in favour of the board director as a significant component for the internal corporate governance processes and mechanisms. In agreement, Fama and Jensen (1983) revealed that the presence of board directors contributes a significant way out of the agency issues that might arise due to ownership and management separation. Similarly, Martín and Herrero (2018) described the board directors as fundamental component of corporate governance. An additional advantage is that risk analysis enhances teamwork simply by increasing the level of 
INTERNATIONAL JOURNAL OF ACADEMIC RESEARCH IN BUSINESS AND SOCIAL SCIENCES Vol. 10, No. 3, March, 2020, E-ISSN: 2222-6990 @ 2020 HRMARS

openness, truthfulness and comprehension within teams and the organization as a whole (Fama \& Jensen, 1983). Several other studies established the link between several characteristics of the board with the performance of firms (Jensen, 1993; Jensen \& Meckling, 1976; Kiel \& Nicholson, 2003; Saibaba, 2013; Adams \& Mehran, 2012; Johl et al., 2015). From the findings of these and other studies, the implied main attributes of the board of directors are board size, board independence, board meetings, board age, and board committee, which collectively, have an impact on the effectiveness of boards performing their oversight roles.

\section{Regulation Impact}

The above discussed external and internal measures, more particularly, the external policy and regulatory measures, are aimed at regulating the performance of banks, risk mitigation, and by extension, protect the economy, which could be majorly affected by instability in the banking sector. Indeed, banking institutions are crucial and sensitive elements of the economy of any country. Accordingly, it is a highly a regulated sector. Aebi et al. (2012) posited that one of the unique characteristics of the banking and by extension the financial services sector is the opaqueness and heavy government regulation and intervention. In agreement, Laeven and Levine (2009) opined that the banking industry is highly regulated, but very dynamic, which in some cases sees banks innovate around regulation, or circumvent such regulations to take risks that are detrimental to business operations in entirety. Similarly, in agreement with Laeven and Levine (2009), Agoraki et al. (2011) argued that bank capital requirements laws and regulations increases the business owners' risk exposure, and are therefore less incentivized to take high risks. Further, in concurrence with the postulations in the other studies, Pathan (2009) observed that in their activities, such as lending or issuing loans, banks have to adhere to the provisions of different laws and regulations, such as the requirements for issuance of loans, they have to adhere to the laws, regulation or legislation on loans. Similarly, Berger et al. (2016) opined that in the future, regulatory agencies should consider putting in place regulations for compensation programs to mitigate executive management greed. Indeed, Power (2004 p.21) argued that it has become increasingly accepted that when the regulation works with the grain of private control systems, it is likely to be more effective and more satisfactory. Accordingly, it is imperative to try and marry these different regulatory and other measures, internal and external, for effective and efficient risk management in the banking sector.

\section{The Risk}

To contextualize the measures implemented to manage risk in the banking industry, including external and internal measures, it is imperative to evaluate and understand what is risk and the nature of risk. The term risk has many meanings. As observed by Crowe and Horn (1967); Denenberg (1964), risk is the uncertainty or loss. Similarly, Mehr and Cammack (1961) also assert that risk is the uncertainty about loss. Greene at al. (1968) point out that risk is the uncertainty as it may result in economic loss. Knight (1921) delineates risk as measurable uncertainty. According to Rable (1968), the traditional delineation of risk takes into account the uncertainty regarding loss. Willett (1951) insists that risk is the objectified uncertainty concerning future undesirable event. Accordingly, from these studies, it can be concluded that risks are usually associated with weak communication channels within institutions, which may result in losses. In this context, and conventionally, risk has been measured using the standard deviation of the expected results from the actual result. Although 
the uncertainty is the situation faced by all businesses in the exercise of their activities, this situation is considered deeper in financial institutions, especially banking, due to the nature of the activities of these institutions, which are based on trading with customers or clients' funds and work to maximize their financial position by seeking to mitigate the risks of a situation. Within the context of the banking and financial services sector, there are different types of risks, which the management of the institutions need to identify, understand, and take appropriate measures to ensure that they do not adversely affect the operations of the business.

\section{Credit Risk}

Credit risk is the risk arising due to non-instantaneous payment for the good or services rendered. It is the risk arising from the provision of credit to consumers or customers. According to Allen and Gale (2004), credit risk considers the loans granted by banks to customers, which may or may not be repaid. Peters (2007); Ghenimi et al. (2017) continuously emphasize that the most important risk for banks is the traditional approach of providing financial services to their customers through credit and loans, which ultimately increases banks' credit risk. In measuring credit risk, there are studies that have been conducted by Ahmed and Khan (2005); Abedifar et al. (2014); Khediri et al. (2015); Chen and Lin (2016); Safiullah and Shamsuddin (2017) which have indicated that the most appropriate approach is to quantify credit risk as a ratio of non-performing loans to the gross loans. Therefore, this study follows above mentioned previous studies and will measure credit risk as in equation 1 below:

$$
\text { Credit Risk }=\frac{\text { Non-performing loan }}{\text { Gross loan }}
$$

\section{Liquidity Risk}

Another important type of risk is the liquidity risk. According to Elbadry (2018), liquidity risk arises once a bank cannot fulfil its financial obligations and future needs, without affecting its financial condition. In agreement, Dang (2011), posited that liquidity reflects the bank ability to meet its obligations. Khediri et al. (2015) measured liquidity risk by using ratio of cash available to the total asset. Implied from these definitions is that liquidity has an impact on the performance of banks because they cannot meet their obligations if they are not liquid enough. However, findings by Said and Tumin (2011) showed that the liquidity of a bank and bank performance does not have any association. Since this analysis is focusing on banks, risk management is a key requirement by the laws and regulatory measures in place. Indeed, the elements of the liquidity assessment, cash and assets, form aa proportion of capital, which will form a part of the pool of funds available to run the operations of the business (Van den Heuvel, 2002). Accordingly, the use of the cash-to-assets ratio, will help to quantify possibility of banks to settle short-term labilities with high liquid or cash and cash-equivalent assets.

$$
\text { Liquadity Risk }=\frac{\text { Cash }}{\text { Total assets }}
$$




\section{Operational Risk}

Another important risk that should be considered, particularly with in the context of the banking industry is the operational risk. It is a different type of risk, which is clearly enumerated in the study by Ames et al. (2015), who posited that the operational risk is completely different from other bank's risks. In measuring operational risk, a study done by Diallo et al. (2015) used operational expenses to operational revenues ratio. Taking a different approach, studies by Ahmed et al. (2011) and Elbadry (2018) used ratio of net income to total assets for measuring operational risk. The differences in calculating or quantifying operational risk is explained in a study by Kulpa and Magdon (2012) who posited that different approaches were employed by researchers since about $64 \%$ of the operational risk originate through bank procedures. Drawing from the different approaches, and the implied demerits and merits of each of these approaches to quantifying risk, the approaches by Ahmed et al. (2011) and Elbadry (2018) that quantify operational risk as expressed in equation 2 are adopted for use in this study.

$$
\text { Operational risk }=\frac{\text { Net Income }}{\text { Total Asset }}
$$

\section{A Proposed Conceptual Model}

In recent decades, the financial sector has witnessed significant developments resulting from globalization of the sector. It has opened wider avenues for banks and financial institutions to invest and make profits. Alongside the banks benefiting from this rapid development, challenges have emerged that reduce the gains and opportunities, including banking risks that are facing the banking sector. In light of the escalation of these risks, governments have issued many regulations to control the financial transactions in banks (Paun et al., 2014). Indeed, due to the influence of the prevailing local and global circumstances it became imperative for the banking sector to apply the regulations and guidelines issued by Basel and by the respective local regulatory agencies, the central bank. Accordingly, as enumerated, this study focused on examining the impact of several indicators such as financial stability indicator, corporate governance and regulation on bank risk. This study used Panel data of 26 banks in Saudi Arabia for the period ranges from 2010 to 2018. Information content of the variables used in this study will be analyzed using different descriptive statistics such as minimum, maximum, mean, standard deviation, skewness and kurtosis. In addition, preliminary tests will be conducted on dataset, and multiple regressions of Pooled Ordinary Least Square (OLS) as the main multivariate analysis, followed by Fixed Effect and Random Effect models will be employed. However, diagnostic test will be conducted for selection of the appropriate model among the series of static model examined in this study. Diagnostic test such as Breusch and Pagan LM Test and Hausman Test will be conducted to determine best model for this study. In this paper, structural relationship model is proposed among the regulation, corporate governance and their effect on risk in Saudi banks institutions. The proposed model based on an evaluation of the different factors identified in the evaluated studies is as shown on Figure 1 below: 
Figure 1 Proposed Model of the Study

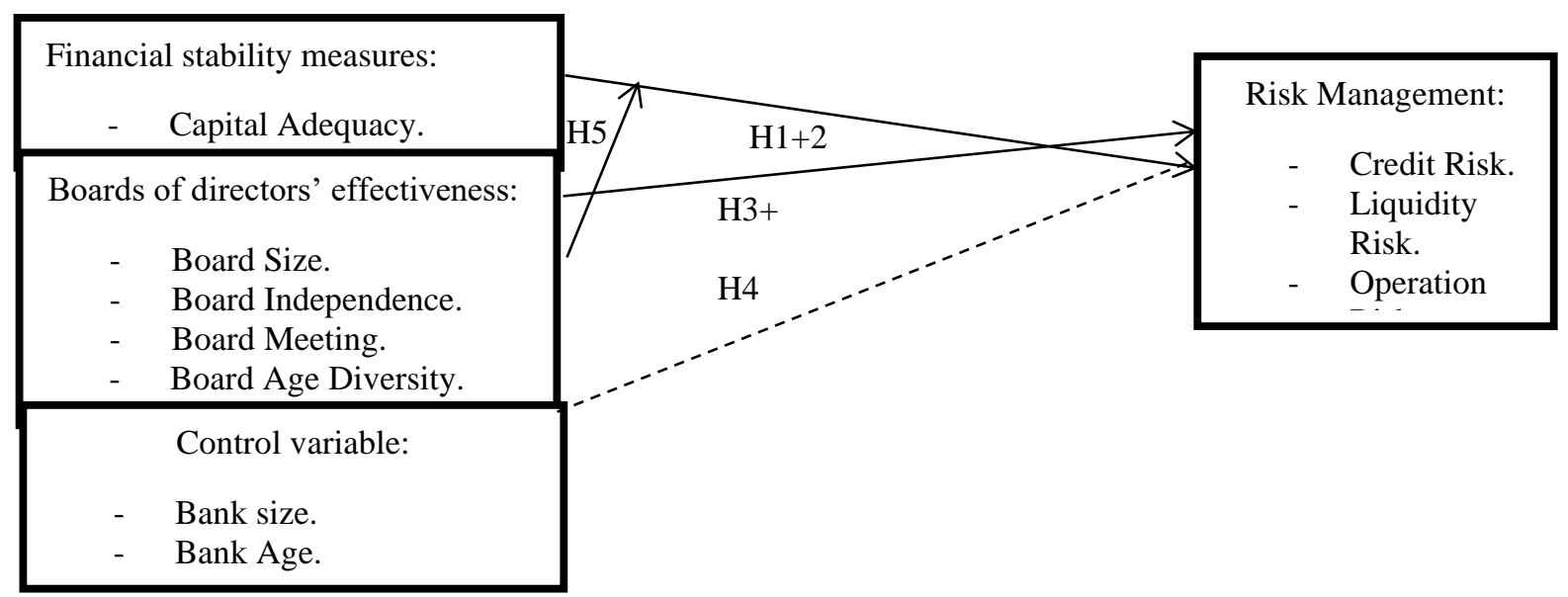

\section{Research Hypotheses}

\section{Capital Adequacy Ratio}

Capital adequacy is a strong indicator that explain financial healthiness of banking institutions. The capital adequacy ratio explicitly details available bank's capital in the form of bank exposure to weighted risk (Furlong \& Keeley, 1989). Kashyap et al. (2002) delineated it as the minimum capital amount necessary to satisfy certain economic restriction on the capital. Blum (1999) makes the argument that capital adequacy aids in making sure that banks have enough bolstering to absorb a practical amount of losses preceding to becoming insolvent and subsequently losing deposit made by the bank customer. According to Kapila and Kapila (2006), regulators impose minimum capital requirements to make sure that banks have a strong financial position in order to remain solvent in times of unforeseen events and serious losses. Additionally, Nwankwo (1991) classified the practical significance of capital into three wide-ranging or phases of a bank's processes, which holistically determine the firm's capital commitment in line with regulatory restrictions.

According to Babihuga (2007), the adequate capital requirements are issued by central bank in a particular country in line with the international standard of capital adequacy laid down by the Basel Accord. As reported by Benli (2010) Basel Accord emphasizes on the capital adequacy ratio which is represented by proportion of assets to weighted risk. Consequently, keeping enough capital helps a bank to solve problems and encourage the continuance of an effective and safe market (Zhou, 2011). Moreover, Naceur and Kandil (2009) revealed that the implementation of the requirements of Basel Accord in economies and the constrict of capital regulation positively impact bank's financial efficiency and also reduce bank risk. Alexander et al. (2013) identify direct effect of the bank capital requirement on financial performance and efficiency. Consistent with their results, when the bank create portfolios regarding the requirement of the Basel that could tolerate certain degree of losses. Takáts and Tumbarello (2009) contend that the capital requirement might positively influence bank efficiency when managing the ethical risk between shareholders, and debt holders. 
INTERNATIONAL JOURNAL OF ACADEMIC RESEARCH IN BUSINESS AND SOCIAL SCIENCES

Vol. 10, No. 3, March, 2020, E-ISSN: 2222-6990 @ 2020 HRMARS

However, Barth et al. (2004) revealed that existence of strong regulators and capital requirement for most countries do not increase bank efficiency. Jarrow (2013); Salem (2013) also, found direct impact of agency costs between shareholders and manager on capital cost. Similarly, Berger and Patti (2006) confirmed negative impact of capital adequacy requirement on banking efficiency of the US. Nevertheless, Lee and Hsieh (2013) maintain that bank performance have been influenced by capital requirements. The findings by Demirgüç-Kunt and Detragiache (2011) on capital requirement and efficiency of the banks was contrary to the previous studies conclusion, noting there is no established link between efficiency of the capital regulation requirement and bank risk. According to Bluhm et al. (2016), when there is a reliable management, the banking regulators will be conscious of taking credit risk level of the bank in to account on issuing of requirement for bank's capital. Accordingly, considering the different positions evaluated, the following hypothesis is developed:

H1: Capital adequacy ratio (Capital requirement) is statistically significant and inversely linked with Saudi's bank risk.

\section{Laon to Deposit Ratio}

The ratio of loan to deposit provides information about the total amount the bank releases as loans to customers relative to the total capital. Ratio of loan to deposit is a reliable indicator for measuring liquidity and banking institutions' stability. LTD is considered as the main indicator for quantifying bank's profitability (Rengasamy, 2014). Several studies also used LTD to evaluate profitability of the bank. The studies by Naceur ( 2003) examined loans and deposit and profitability of the bank; and Rengasamy (2014) identified ratio of loan to deposit as well as profitability in Malaysian commercial banks. The higher the LTD, the more interest loans issued from deposits. The more the interest loan allowed by the banks the more income and the higher risk (Rengasamy, 2014; Elbadry, 2018). Accordingly, drawing from the arguments presented, the second hypothesis developed avers that a higher percentage of loans to deposits has detrimental impact on the liquidity profile of banks in Saudi Arabia as this hampers their ability to provide adequate liquidity and perform their settlement roles. This challenge is compounded into multipronged layers of risk in the event of highly risk phenomena like economic meltdowns and other events that could lead to loan defaults (Collings \& Taillard, 2013). Similarly, findings by Elbadr (2018) are consistent with earlier studies on financial stability of Saudi Arabia banks on risk management. Hypothesis $2\left(\mathrm{H}_{2}\right)$ was developed based on the evaluation of the above arguments:

H2: Loan to deposit (LTD) ratio is statistically significant and positively related to the Saudi banks risk.

\section{Board Size}

Size of bank board members, in terms of the number of people included in a board is known as Board size (Amran, 2011). As stated by Xie et al. (2003); Mohd-Said et al., (2018) board size becomes a significant determinant of how an organization performs. Conclusions and views on the impact of board size on performance and risk management in organization are conflicting. Therefore, there is no consensus among researchers on the number of people that constitute an ideal board size for bank effectiveness (Jensen, 1993; Hermalin \& Weisbach, 2003). Previous studies presented two 
INTERNATIONAL JOURNAL OF ACADEMIC RESEARCH IN BUSINESS AND SOCIAL SCIENCES

Vol. 10, No. 3, March, 2020, E-ISSN: 2222-6990 @ 2020 HRMARS

different point of view. First view was small size of boards positively affected firms' performance (Jensen, 1993; Lipton \& Lorsch, 1992) while second view was larger boards would enhance the performance of the firms (Klein, 1998; Adams \& Mehran, 2003; Coles et al., 2008; Pathan \& Faff, 2013; Bhatt \& Bhattacharya, 2015; Bansal \& Sharma, 2016). Based on Jensen (1993); Lipton and Lorsch (1992) proposed the unit of board size to be either seven or eight members at most in order to encourage the firms to perform effectively. When the number of the boards is large, it reduces the efficiency of the boards. In addition, it becomes hard for the independents directors to control and make a decision (Lipton \& Lorsch, 1992; Jensen, 1993).

However, several studies have showed that the larger the board, the better the firm performance. Studies by Klein (1998); Adams and Mehran (2003); Coles et al. (2008) supported large boards because their ability to control and guidance. Klein (1998) argued that CEO guidance is essentially required in complex organizations with multiple diverse sections. Similarly, large and compositionally diverse board directors is instrumental for risk oversight in the bank as it would have the necessary personnel to evaluate all potential for risk and deliberate on the right mitigating strategies (De Vita \& Luo, 2018). The agency theory debates that the larger the board size the lesser the disagreement between shareholders and management. Due to the role that the board takes in relation to the firm's management's actions (Kiel \& Nicholson, 2003; Amran et al., 2010). From the two points of view, the following hypothesis $3 a\left(\mathrm{H}_{3 a}\right)$ is developed:

H3a: Board of directors' size is statistically significant and inversely related to the Saudi banks risk.

\section{Board Independence}

Consistent with the agency theory, board independence affords better effective management by oversighting the agent-principle or management-shareholders relationship. In this respect, Nicholson and Kiel (2007) contend that uneven knowledge of business understanding exist between inside directors and outside directors. Some studies recommended that association between the independent boards and firm performance is directly related (Lin, 2011; Dharmadasa et al., 2014; Mohd-Said et al., 2018). Also, MacAvoy and Millstein (1999) established direct and significant association between the independent boards and firm performance. Several studies concluded that outside independent director could prevent agency theory by protecting the interest of shareholders to achieve their specific objectives (Brickley \& James, 1987; Byrd \& Hickman, 1992). Several studies stated that effectiveness governance with independent outside directors improve firm performance (Baysinger \& Butler, 1985). In accordance with above argument, hypothesis $3 b\left(\mathrm{H}_{3 b}\right)$ is developed:

H3b: Independence board director is statistically significant and inversely related to Saudi bank risks.

\section{Board Meeting Attendance}

As a further explanation of agency theory, operational diligence on the part of the board of directors reflects their ability to meet their obligations as transactional agents in the banking institution (Adams \& Mehran, 2012). Also, Grove et al. (2011) point out that board meetings are significant governance mechanisms that influence the risk profile of banks. Other proponents of this view findings by Schwartz-Ziv and Weisbach (2013) with an argument that board meetings are 
indispensable in the monitoring and reporting mechanism to banks. Mersland and Strøm (2009) contend that bank board meetings are crucial platforms for seeking consensus on governance issues and can improve responsible risk-taking behavior to a great extent with higher frequency meetings. Also, recommendation by Van den Berghe (2012) suggests that board meetings should be deliberately designed to increase participation of members. Assigning responsibility to the board in the form of committees is extremely important as it allows for the opportunity to address all issues and agenda before the board (Mason \& Asher, 2010). However, Minichilli et al. (2009) disputed overriding significance of number of board meetings, arguing that other pertinent issues hold greater importance as far as effective board governing is concerned. These views were inconsistent with the finding by Lassoued et al. (2016), on the number of meetings has little significance as long as there is a stable and reliable structure behind the operations of the board. Hence, the following hypothesis is developed:

H3c: Board of directors' frequency meeting is statistically significant and inversely related to Saudi bank risks.

\section{Age Diversity of Board Members}

Boards' effectiveness is usually reflected by highly skilled and experienced managers, and these features come with age. However, there is no regulatory guidance to limit the age of the board members. Companies employ board members according to their unique skill. Some studies established relatedness between age and risk. According to Child (1974); Wiersema and Bantel (1992), the younger the manager becomes, the riskier they are likely to be. On the other hand, the aging of executives makes them more cautious (Sevens et al., 1978). A correlation between maturity and moral development is that older decision makers are looking for more information to make decision, therefore take enough time to make an effective decision and often arrived at more accurate decision (Daboub et al., 1995).

According to Carlsson and Karlsson (1970), the older members of the board prefer the more financial security and the more secure in maintaining their jobs. On the other hand, Eulerich et al. (2014) examined German firms during the period of 2009-2011 involving 149 firms. They argued that board's age is negatively affected on the firm performance. Contrary to majority of previous studies is the conclusion by Akpan and Amran (2014) that board age and performance has no relationship after examined 90 Nigerian firms over the period 2010-2012. Accordingly, the more the age diversity among board members the lower the risk appetite for the firm. From these arguments Hypothesis $3 d$ $\left(\mathrm{H}_{3 \mathrm{~d}}\right)$ is formed:

H3d: Age diversity of board directors is statistically significant and inversely related to Saudi bank risks.

\section{Board Committees}

The boards of directors contribute significantly towards operational as well as decision-making directive of the banks. This making them indispensable in determining the banks' risk dynamics and risk mitigation. Board effectiveness could be improved by board committees (Hoitash et al., 2009). In the context of Saudi Arabia, guidelines and the legislation are focused on corporate governance in 
INTERNATIONAL JOURNAL OF ACADEMIC RESEARCH IN BUSINESS AND SOCIAL SCIENCES Vol. 10, No. 3, March, 2020, E-ISSN: 2222-6990 @ 2020 HRMARS

relation to employment of board committees, specifically audit, remuneration (compensation) and nomination (Saudi Arabia Monetary Authority [SAMA], 2014). From the agency viewpoint, Fama and Jensen (1983), compensation and nominating committees have important roles in the process of decision-making. The Audit, Remuneration and Nomination Committees provide empirical evidence as well as independent review of the company's affairs. Vafeas (2000) stated that the structure of the boards is responsible to the effectiveness of monitoring strategies in the light of information inconsistencies. Laing and Weir (1999) discovered that audit, nominating as well as compensation committees contribute to betterment of the firm. Thus, Hypothesis $3 e\left(\mathrm{H}_{3 e}\right)$ is proposed.

H3e: Board of directors' committee is statistically significant and inversely related to Saudi bank risks.

\section{Board of Directors Characteristics Index}

As argued by Pathan (2009) that the significant factors that determine board effectiveness are quantity of the board members, board independence, non-staggered and no poison pills.. On the other hand, Mollah and Zaman (2015) debated that board effectiveness is determined by board size and board independence. Liang, Xuc and Jiraporn (2013) revealed that core determinant of effectiveness is quantify by regularity of board meeting, board size, and board independence. In agreement, Martín and Herrero (2018) suggest that the larger the board size and board independence the better the performance of the firms. They reported that the diversity included (age, gender, and nationality) can influence the awareness, capability and proficiencies of the directors. According to Ward et al. (2009), governance mechanisms labor is an integral or commutable method. Therefore, it is important to explore the mechanisms as bunch of instruments in order to safeguard shareholder. Due to above arguments, Hypothesis $4\left(\mathrm{H}_{4}\right)$ is proposed.

H4: Board of directors' effectiveness index is statistically significant and inversely related to Saudi bank risks.

\section{Board of Directors Effectiveness as Moderator}

The role of board directors is crucial in moderating the risk appetite of the firm and risk management. Secondly, the capital requirement regulation does not affect the efficiency and risk of banks (Demirgüç-Kunt \& Detragiache, 2011). Finally, board individual characteristics (such as board size and board independence) is essential which its omission may result to wrong inferences relationship between bank regulation and the risk-taking (De Vita \& Luo, 2018). In their study, they contributed to the knowledge by examining this relationship. Accordingly, hypothesis $5\left(\mathrm{H}_{5}\right)$ is proposed.

H5: Capital adequacy ratio (Capital requirement) is more likely to affect risk of Saudi banks positively and significantly when banks have effective board of directors, as represented by board of directors' effectiveness index.

\section{Conclusions}

The banking industry is highly susceptible to shocks in the operating environment, such as the financial crises of 1997 and 2008 in Asia and globally respectively. By virtue of their operations, banks are highly susceptible to various types of risks, including liquidity, operational, and credit risks if not 
INTERNATIONAL JOURNAL OF ACADEMIC RESEARCH IN BUSINESS AND SOCIAL SCIENCES Vol. 10, No. 3, March, 2020, E-ISSN: 2222-6990 @ 2020 HRMARS

well managed. Cognizant of these risks, and in the face of many challenges that have bedeviled the banking sector globally, international organizations, such as the Basel Committee on Banking Supervision, as well as regional and local institutions have formulated and implemented measures to foster operational efficiency by mitigating the different risks. Indeed, corporate governance has been proposed and is leveraged as one of the measures for mitigating risks in the banking and financial services sector. Accordingly, the regulatory and policy framework, at the international and national level, guidelines by regulatory agencies, such as SAMA, and the legislative framework by the government provide a foundation for the formulation and implementation of measures to mitigate risks and foster operational efficiencies in the banking sector. In addition, corporate governance, including board size, independence, frequency of meetings, age, and composition, as well as the existence and implementation of a code of conduct and ethics are likely to foster responsible operations, mitigate different risks, and in so doing, foster stability in one institution, and collectively, in the sector in a country, and globally. With an understanding of the different risks, the remedial actions by different players, and the status of the industry, the management of banking institutions is likely to be more proactive, formulating and implementing measures that foster stability by taking well-calculated strategies that mitigate any challenges and risks likely to face individual institutions or the industry in general.

\section{References}

Abdelrahim, K. (2013). Effectiveness of Credit Risk Management of Saudi Banks in the Light of Global Financial Crisis: A Qualitative Study. Asian Transactions on Basic and Applied Sciences, 03(02), 2221-4291. Retrieved from http://asiantransactions.org/Journals/Vol03Issue02/ATBAS/ATBAS-10305028.pdf

Acharya, V. V., Cooley, T. F., Richardson, M. P., \& Walter, I. (2011). Market Failures and Regulatory Failures: Lessons from Past and Present Financial Crises. SSRN Electronic Journal. https://doi.org/10.2139/ssrn.1757711

Adams, R. B., \& Mehran, H. (2003). Is Corporate Governance Different for Bank Holding Companies? Economic Policy Review, 9(1).

Adams, R., \& Mehran, H. (2012). Bank board structure and performance: Evidence for large bank holding companies. Journal of Financial Intermediation, 21(2), 243-267.

Aebi, V., Sabato, G., \& Schmid, M. (2012). Risk management, corporate governance, and bank performance in the financial crisis. Journal of Banking and Finance, 36(12), 3213-3226. https://doi.org/10.1016/j.jbankfin.2011.10.020

Agoraki, M. E. K., Delis, M. D., \& Pasiouras, F. (2011). Regulations, competition and bank risk-taking in transition countries. Journal of Financial Stability, 7(1), 38-48. https://doi.org/10.1016/j.jfs.2009.08.002

Ahmed, N., Ahmed, Z., \& Naqvi, I. H. (2011). Liquidity Risk and Islamic Banks : Evidence from Pakistan. Interdisciplinary Journal of Research in Business, 1(9), 99-102. https://doi.org/10.1016/j.conengprac.2007.02.010

Akpan, E. O., \& Amran, N. A. (2014). Board characteristics and company performance: Evidence from Nigeria. Journal of Finance and Accounting, 2(3), 81-89.

Al-Maghzom, A., Hussainey, K., \& Aly, D. (2016). The level of Risk Disclosure in Listed Banks : Evidence from Saudi Arabia. Corporate Ownership and Control, 14(1), 175-194. 
INTERNATIONAL JOURNAL OF ACADEMIC RESEARCH IN BUSINESS AND SOCIAL SCIENCES Vol. 10, No. 3, March, 2020, E-ISSN: 2222-6990 @ 2020 HRMARS

Alexander, G. J., Baptista, A. M., \& Yan, S. (2013). A comparison of the original and revised Basel market risk frameworks for regulating bank capital. Journal of Economic Behavior \& Organization, 85, 249-268.

Allen, F., \& Gale, D. (2004). Financial Intermediaries and Markets. Econometrica, 72(4), 1023-1061.

Alzgool, M. (2019). Nexus between Green HRM and Green Management towards Fostering Green Values. Management Science Letters, 9(12), 2073-2082.

Ames, M., Schuermann, T., \& Scott, H. S. (2015). Bank capital for operational risk: A tale of fragility and instability". Journal of Risk Management in Financial Institutions, 8(3), 227-243.

Amran, A., Ishak, M. S., Zulkafli, A. H., \& Nejati, M. (2010). Board structure and extent of corporate governance statement. International Journal of Managerial and Financial Accounting, 2(4), 383400.

Amran, N. A. (2011). Corporate Governance Mechanisms and Company Performance : Evidence from Malaysian Companies. International Review of Business Research Papers, 7(6), 101-114.

Ayadi, N., \& Boujelbene, Y. (2014). The role of capital regulation on bank performance. International Journal of Managerial and Financial Accounting, 6(3), 203-226.

Babihuga, R. (2007). Macroeconomic and Financial Soundness Indicators : An Empirical Investigation (No. 7-115).

Bansal, N., \& Sharma, A. (2016). Audit Committee,Corporate Governance and Firm Performance:Empirical Evidence from India. International Journal of Economics and Finance, $8(3)$.

Barnhart, S. W., Marr, M. W., \& Rosenstein, S. (1994). Firm performance and board composition: Some new evidence, 15(4), 329-340.

Barth, J. R., Caprio, Jr, G., \& Levine, R. (2004). Bank regulation and supervision: what works best? Journal of Financial Intermediation, 13(2), 205-248.

Basel Committee on Banking Supervision. (2005). Amendment to the Capital Accord to Incorporate Market Risks.

Basel Committee on Banking Supervision. (2006). International Convergence of Capital Measurement and Capital Standards.

Basel Committee on Banking Supervision. (2015). Basel Committee on Banking Supervision Guidelines Corporate governance principles for banks.

Basle. (1988). Basle Committee on Banking Supervision International Convergence of Capital Measurement and Capital Standards.

Baysinger, B. D., \& Butler, H. N. (1985). Corporate Governance and the Board of Directors: Performance Effects of Changes in Board Composition. Journal of Law, Economics, \& Organization, 1(1), 101-124.

Bebchuk, L., Cohen, A., \& Ferrell, A. (2009). What Matters in Corporate Governance? Review of Financial Studies, 22(2), 783-827.

Benli, V. F. (2010). A Critical Assessment of Basel II, Internal Rating Based Approach: Implementation in Emerging Markets: The Case of Turkey. Haupt Verlag AG.

Berger, A. N., Imbierowicz, B., \& Rauch, C. (2016). The roles of corporate governance in bank failures during the recent financial crisis. Journal of Money, Credit and Banking, 48(4), 729-770.

Berger, A. N., \& Patti, E. B. (2006). Capital structure and firm performance: A new approach to testing agency theory and an application to the banking industry. Journal of Banking \& Finance, 30(4), 
INTERNATIONAL JOURNAL OF ACADEMIC RESEARCH IN BUSINESS AND SOCIAL SCIENCES

Vol. 10, No. 3, March, 2020, E-ISSN: 2222-6990 @ 2020 HRMARS

1065-1102.

Bhagat, S., Bolton, B., \& Romano, R. (2008). The Promise and Peril of Corporate Governance Indices. Columbia Law Review, 108(08).

Bhatt, R. R., \& Bhattacharya, S. (2015). Board structure and firm performance in Indian IT firms. Journal of Advances in Management Research, 12(3).

Bluhm, C., Overbeck, L., \& Wagner, C. (2016). Introduction to Credit Risk Modeling. CRC Press.

Blum, J. (1999). Do capital adequacy requirements reduce risks in banking? Journal of Banking and Finance, 23(5), 755-771. https://doi.org/10.1016/S0378-4266(98)00113-7

Brickley, J., \& James, C. (1987). The Takeover Market, Corporate Board Composition, and Ownership Structure: The Case of Banking. Journal of Law and Economics, 30(1), 80-161.

Byrd, J. W., \& Hickman, K. A. (1992). Do outside directors monitor managers? Evidence from tender offer bids. Journal of Financial Economic, 32(2), 195-221.

Carlsson, G., \& Karlsson. (1970). Age, Cohorts and the generation of generation. American Sociological Review, 35, 710-718.

Child, J. (1974). What detennines organization perfonnance? The universals vs the it-all-depends. Organizational Dynamics, 3(1), 2-18.

Chouaibi, J., Boujelbene, Y., \& Affes, H. (2009). Characteristics of the Board of Directors and Involvement in Innovation Activities: A Cognitive Perspective. International Journal of Managerial and Financial Accounting, 5(3), 34-44.

Coles, J. L., Daniel, N. D., \& Naveen, L. (2008). Boards : Does one size fit all ? Journal of Financial Economics, 87, 329-356. https://doi.org/10.1016/j.jfineco.2006.08.008

Collings, S., \& Taillard, M. (2013). Corporate Finance for Dummies. John Wiley \& Sons.

Conyon, M. J. (1997). Corporate governance and executive compensation. International Journal of Industrial Organization, 15(4), 493-509. https://doi.org/10.1016/S0167-7187(96)01032-6

Crowe, R. M., \& Horn, R. C. (1967). The Meaning of Risk. The Journal of Risk and Insurance, 34(3), 459-474.

Darwish, S., \& Abdeldayem, M. M. (2019). Risk Management and Business Ethics: Relations and Impacts in the GCC. International Journal of Civil Engineering and Technology, 10(10), 489-504.

Darwish, S. Z. (2015). Risk and Knowledge in the Context of Organizational Risk Management. Risk, 7(15).

Daboub, J., Rasheed, A. M. A., Priem, R. L., \& Gray, D. A. (1995). Top Management Team Charactenstlcs and Corporate megal Activity. The Academy of Management Review, 20(1), 138170.

Dang, U. (2011). The CAMEL Rating System in Banking Supervision: a Case Study. Arcada University of Applied Sciences, International Business.

De Vita, G. \&, \& Luo, Y. (2018). When do regulations matter for bank risk-taking? An analysis of the interaction between external regulation and board characteristics. CORPORATE GOVERNANCE, 18(3), 440-461.

Decamps, J. P., Rochet, J. C., \& Roger, B. (2004). The three pillars of Basel II: Optimizing the mix. Journal of Financial Intermediation, 13(2), 132-155. https://doi.org/10.1016/j.jfi.2003.06.003

Demerjian, P. (2007). "Financial Ratios and Credit Risk: The Selection of Financial Ratio Covenants in Debt Contracts. AAA 2007 Financial Accounting \& Reporting Section (FARS) Meeting Paper.

Demirgüç-Kunt, A., \& Detragiache, E. (2011). Basel core principles and bank soundness: Does 
INTERNATIONAL JOURNAL OF ACADEMIC RESEARCH IN BUSINESS AND SOCIAL SCIENCES

Vol. 10, No. 3, March, 2020, E-ISSN: 2222-6990 @ 2020 HRMARS

compliance matter? Journal of Financial Stability, 7(4), 179-190.

Denenberg, H. S. (1964). Risk and insurance. New York. Prentice-Hall.

Dharmadasa, P., Gamage, P., \& Herat, S. K. (2014). Corporate Governance, Board Characteristics and

Firm Performance: Evidence from Sri Lanka. Journal of South Asian Development, 21(1), 7-13.

Diallo, O., Fitrijanti, T., \& Tanzil, N. D. (2015). Analysis of The Influence of Liquidity, Credit and Operational Risk, in Indonesian Islamic Bank's Financing for The Period 2007-2013. International Journal of Business, 17(3), 279-294. https://doi.org/10.22146/gamaijb.8402

Dierick, F., Pires, F., Scheicher, M., \& Spitzer, K. G. (2005). The New Basel Capital Framework and its Implementation in the European Union. European Central Bank. Retrieved from http://www.ecb.int/pub/pdf/scpops/ecbocp42.pdf

Dulewicz, V., \& Herbert, P. (2004). Does the composition and practice of boards of directors bear any relationship to the performance of their companies? Corporate Governance: An International Review, 12(3), 263-280. https://doi.org/10.1111/j.1467-8683.2004.00368.x

Elbadry, A. (2018). Bank's financial stability and risk management. Journal of Islamic Accounting and Business Research, 9(2), 119-137. https://doi.org/10.1108/JIABR-03-2016-0038

Eulerich, M., Velte, P., \& Uum, C. v. (2014). The impact of management board diversity on corporate performance-an empirical analysis for the German two-tier system. Problems and Perspectives in Management, 12(1), 25-39.

Fama, E. F. (1980). Agency Problems and The Theory of The Firm. Journal of Political Economy, 88(2), 288-307. https://doi.org/10.1086/260866

Fama, E. F., \& Jensen, M. C. (1983). Separation of ownership and control. Journal of Law and Economics, 26(2), 301-325. https://doi.org/10.4324/9780203888711

Fratianni, M., \& Marchionne, F. (2009). The Role of Banks in the Subprime Financial Crisis (Working Papers No. 2009-02). Indiana University, Kelley School of Business, Department of Business Economics and Public Policy.

Friewald, N., Wagner, C., \& Zechner, J. (2014). The Cross-Section of Credit Risk Premia and Equity Returns. Journal of Finance, 69(6), 2419-2469. https://doi.org/10.1111/jofi.12143

Furlong, F. T., \& Keeley, M. C. (1989). Capital Regulation and Rank Risk-Taking: A Note. Journal of Banking \& Finance, 13(1977), 883-891. https://doi.org/10.1073/pnas.1311996110

Ghenimi, A., Chaibi, H., \& Omri, M. A. B. (2017). The effects of liquidity risk and credit risk on bank stability: Evidence from the MENA region. Borsa Istanbul Review, 17(4), 238-248. https://doi.org/10.1016/j.bir.2017.05.002

Gompers, P., Ishii, J., \& Metrick, A. (2003). Corporate Governance and Equity Prices. The Quarterly Journal of Economics, 118(1), 107-156.

Greene, M. R., Trieschmann, J. S., \& Gustavson, S. G. (1985). The structure of corporate ownership: causes and consequences. Journal of Political Economy, 93(6), 1155-1177. https://doi.org/10.1038/249009b0

Greene, M. R., Trieschmann, J. S., \& \& Gustavson, S. G. (1968). Risk and insurance. New York: SouthWestern Publishing Company.

Grove, H., Patelli, L., Victoravich, L., \& Xu, P. (2011). Corporate governance and performance in the wake of the financial crisis: Evidence from US commercial banks. Corporate Governance: An International Review, 19(5), 418-436.

Heid, F. (2007). The cyclical effects of the Basel II capital requirements. Journal of Banking and 
INTERNATIONAL JOURNAL OF ACADEMIC RESEARCH IN BUSINESS AND SOCIAL SCIENCES

Vol. 10, No. 3, March, 2020, E-ISSN: 2222-6990 @ 2020 HRMARS

Finance, 31(12), 3885-3900. https://doi.org/10.1016/j.jbankfin.2007.03.004

Hermalin, B. E., \& Weisbach, M. S. (2003). Boards of Directors as an Endogenously Determined Institution: A Survey of the Economic Literature. Economic Policy Review, 9(1).

Hoitash, U., Hoitash, R., \& Bedard, J. C. (2009). Corporate governance and internal control over financial reporting: a comparison of regulatory regimes. Accounting Review, 84(3), 839.

Hudson, R. (2003). Dealing with Basel II: Basel II - the end of risk management? Balance Sheet, 11(4), 32-35. https://doi.org/10.1108/09657960310502539

International Monetary Fund. (2017). FINANCIAL SYSTEM STABILITY ASSESSMENT.

Ivashina, V., \& Scharfstein, D. (2010). Bank lending during the financial crisis of 2008. Journal of Financial Economics, 97(3), 319-338. https://doi.org/10.1016/j.jfineco.2009.12.001

Jarrow, R. (2013). A leverage ratio rule for capital adequacy. Journal of Banking \& Finance, 37(3), 973976.

Jayadev, M. (2013). Basel III implementation: Issues and challenges for Indian banks. IIMB Management Review, 25(2), 115-130. https://doi.org/10.1016/j.iimb.2013.03.010

Jensen, M. C. (1993). The modern industrial revolution, exit, and the failure of internal control systems. The Journal of Finance, 48(3), 831-880.

Jensen, M. C., \& Meckling, W. H. (1976). Theory of the Firm: Managerial Behavior, Agency Costs and Ownership Structure. Journal of Financial Economics, 3(4), 305-360. Retrieved from http://ssrn.com/abstract=94043http://hupress.harvard.edu/catalog/JENTHF.html

Johl, S. K., Kaur, S., \& Cooper, B. J. (2015). Board Characteristics and Firm Performance : Evidence from Malaysian Public Listed Firms. Journal of Economics, Business and Management, 3(2), 239243. https://doi.org/10.7763/JOEBM.2015.V3.187

John, K., Litov, L., \& Yeung, B. (2008). Corporate Governance and Risk Taking. Journal of Finance, 36(4), 1679-1728.

Jokipii, T. K. (2009). Bank Capital Management. https://doi.org/10.1134/S1054660X07040196

Jorion, P. (2007). Value at Risk, 3rd Ed.: The New Benchmark for Managing Financial Risk (Third Edit). McGraw-Hill.

Kapila, R., \& Kapila, U. (2006). India's Economy: A Journey in Time and Space. Academic Foundation.

Kashyap et al. (2002). Banks as Liquidity Providers: An Explanation for the Coexistence of Lending and Deposit- Taking. Journal of Finance, 57(1), 33-73.

Khediri, K., Charfeddine, L., \& Youssef, S. (2015). Islamic versus conventional banks in the GCC countries: A comparative study using classification techniques. Research in International Business and Finance, 33, 75-98. https://doi.org/10.1016/j.ribaf.2014.07.002.

Khalid, N., Islam, D. M. Z., \& Ahmed, M. R. M. (2019). Sentrepreneurial Training and Organizational Performance: Implications for Future. Humanities \& Social Sciences Reviews, 7(2), 590-593.

Kiel, G. C., \& Nicholson, G. J. (2003). Board Composition and Corporate Performance: how the Australian experience informs contrasting theories of corporate governance. Corporate Governance: An International Review, 11(3), 189-205.

Klein, A. (1998). Firm Performance and Board Committee Structure. Journal of Law and Economics, 41(1), 275-303.

Knight, F. H. (1921). Risk, uncertainty and profit. New York: Hart, Schaffner and Marx.

Kulpa, W., \& Magdon, A. (2012). Operational risk management in a bank. Internal Auditing \& Risk Management, 7(4), 35-50. 
INTERNATIONAL JOURNAL OF ACADEMIC RESEARCH IN BUSINESS AND SOCIAL SCIENCES

Vol. 10, No. 3, March, 2020, E-ISSN: 2222-6990 @ 2020 HRMARS

Laeven, L., \& Levine, R. (2009). Bank governance, regulation and risk taking. Journal of Financial Economics, 93(2), 259-275. https://doi.org/10.1016/j.jfineco.2008.09.003

Laing, D., \& Weir, C. M. (1999). Governance structures, size and corporate performance in UK firms. Management Decision, 37(5), 457-464.

Lassoued, N., Sassi, H., \& Attia, M. B. (2016). The impact of state and foreign ownership on banking risk: Evidence from the MENA countries. Research in International Business and Finance, 36, 167-178.

Lee, C. C., \& Hsieh, M. F. (2013). The impact of bank capital on profitability and risk in Asian banking. Journal of International Money and Finance, 32, 251-281.

Liang, Q., Xuc, P., \& Jiraporn, P. (2013). Board characteristics and Chinese bank performance. Journal of Banking \& Finance, 37(8), 2953-2968.

Lin, Y.-H. (2011). Overseeing Controlling Shareholders: Do Independent Directors Constrain Tunneling in Taiwan? International Law Journal, 12, 363.

Lipton, M., \& Lorsch, J. W. (1992). A modest proposal for improved corporate governance. The Business Lawyer, 48(1), 59-77.

MacAvoy, P., \& Millstein, I. (1999). The Active Board of Directors and Improved Performance of the Large Publicly Traded Corporation. Journal of Applied Corporate Finance, 11(4), 8-20.

Martín, C. J. G., \& Herrero, B. (2018). Boards of directors: composition and effects on the performance of the firm. Economic Research-Ekonomska Istraživanja, 31(1), 1-27. https://doi.org/10.1080/1331677X.2018.1436454

Mason, E. S., \& Asher, R. E. (2010). The world bank since Bretton Woods. Brookings Institution Press. Mehr, R. I., \& Cammack, E. (1961). Principles of insurance. New York: RD Irwin.

Mersland, R., \& Strøm, R. $\varnothing$. (2009). Performance and governance in microfinance institutions. Journal of Banking \& Finance, 33(4), 662-669.

Minichilli, A., Zattoni, A., \& Zona, F. (2009). Making boards effective: An empirical examination of board task performance. British Journal of Management, 20(1), 55-74.

Mohd-Said, R., Shen, L. T., Nahar, H. S., \& Senik, R. (2018). Board compositions and social reporting : evidence from Malaysia, 10(2), 128-143.

Mollah, S., \& Zaman, M. (2015). Shari'Ah Supervision, Corporate Governance and Performance: Conventional vs. Islamic Banks. Journal of Banking \& Finance, 58, 418-435.

Naceur, S. Ben. (2003). The determinants of the Tunisian Banking industry profitability: panel evidence.

Naceur, S. B., \& Kandil, M. (2009). The impact of capital requirements on banks' cost of intermediation and performance: The case of Egypt. Journal of Economics and Business, 61(1), 70-89.

Nguyen, P. (2011). Corporate governance and risk-taking: Evidence from Japanese firms. Pacific-Basin Finance Journal, 19(3), 278-297.

Nicholson, G., \& Kiel, G. (2007). Can Directors Impact Performance? A case-based test of three theories of corporate governance. Corporate Governance: An International Review, 15(4), 585608.

NikosVafeas. (2000). Board structure and the informativeness of earnings. Journal of Accounting and Public Policy, 19(2), 139-160.

Ntim, C. G. (2009). Internal Corporate Governance Structures and Firm Financial Performance: 
INTERNATIONAL JOURNAL OF ACADEMIC RESEARCH IN BUSINESS AND SOCIAL SCIENCES

Vol. 10, No. 3, March, 2020, E-ISSN: 2222-6990 @ 2020 HRMARS

Evidence from South African Listed Firms. University of Glasgow.

Nwankwo, G. (1991). Bank management: Principles and practice. Lagos, Nigeria: Malthouse Press Limited.

Ojo, M. (2009). Risk Management by the Basel Committee: Evaluating Progress made from the 1988 Basel Accord to Recent Developments. Journal of Financial Regulation and Compliance, 18(4), 305-315.

Ozkan, C., \& Iqbal, Z. (2015). Implications of Basel III for Islamic Banking- Opportunities and Challenges. The World Bank Group Finance and Markets Group Global Islamic Finance Development Center, 38.

Pathan, S. (2009). Strong boards, CEO power and bank risk-taking. Journal of Banking and Finance, 33(7), 1340-1350. https://doi.org/10.1016/j.jbankfin.2009.02.001

Pathan, S., \& Faff, R. (2013). Does board structure in banks really affect their performance? Journal of Banking \& Finance, 37(5).

Paun, C., Topan, V., \& Musetescu, R. (2014). Financial contracts and financial crisis: the case of demand and term deposits. International Journal of Managerial and Financial Accounting, 7(3), 271-285.

Peni, E., \& Vähämaa, S. (2012). Did Good Corporate Governance Improve Bank Performance during the Financial Crisis? Journal of Financial Services Research, 41(1-2), 19-35. https://doi.org/10.1007/s10693-011-0108-9

Peters, B. (2007). Approaches to measuring, limiting and managing risks, especially those facing small and medium-sized institutions. BIS.

Power, M. (2004). The risk management of everything: Rethinking the politics of uncertainty. London: Demos.

Rable, W. H. (1968). Further comment. Journal of Risk and Insurance, 35(4), 611-612.

Rengasamy, D. (2014). Impact of loan deposit ratio (LDR) on profitability: Panel evidence from commercial banks in Malaysia. In Proceedings of the Third International Conference on Global Business, Economics, Finance and Social Sciences (GB14Mumbai Conference) Mumbai, India ( $p$. : 1-12).

Ronall, J. O. (1967). Banking Regulations in Saudi Arabia. The Middle East Journal, 21(3), 399-402.

Saibaba, M. D. (2013). Audit Committees, Board Structures and Firm Performance: A Panel Data Study of BSE 30 Companies. Journal of Accounting Research, (2).

Said, R. M., \& Tumin, M. H. (2011). Performance and Financial Ratios of Commercial Banks in Malaysia and China. International Review of Business Research Papers, 7(2), 157-169.

Salem, R. A. (2013). Risk Management for Islamic Banks. Edinburgh University Press.

Saudi Arabia Monetary Authority [SAMA]. (2014). Principles of Corporate Governance for Banks Operating in Saudi Arabia. Saudi Arabian Monetary Agency.

Schwartz-Ziv, M., \& Weisbach, M. S. (2013). What do boards really do? Evidence from minutes of board meetings. Journal of Financial Economics, 108(2), 349-366.

Sevens, J. M., Beyer, J. M., \& Trice, H. M. (1978). Assessing personal, role and organizational predictors of managerial commitment. Academy of Management Journal, 21, 380-396.

Shleifer, A., \& Vishny, R. W. (1997). A Survey of Corporate Governance. The Journal of Finance, 52(2), 737-783.

Spong, K. R., \& Sullivan, R. J. (2007). Corporate Governance and Bank Performance. In Benton E. Gup 
INTERNATIONAL JOURNAL OF ACADEMIC RESEARCH IN BUSINESS AND SOCIAL SCIENCES

Vol. 10, No. 3, March, 2020, E-ISSN: 2222-6990 C 2020 HRMARS

(Ed.), Corporate Governance in Banking: A Global Perspective (pp. 40-61). Edward Elgar.

Stiroh, K. J., \& Rumble, A. (2003). The Darkside of Diversification: The Case of U.S. Financial Holding Companies. Journal of Banking and Finance, 30(8), 2131-2161. https://doi.org/10.1016/j.jbankfin.2005.04.030

Svilenova, J. (2011). Regulatory Response to the Financial Crisis of 2007- 2008 Will Basel III Help Prevent Future Crises in the Banking Sector? Retrieved from http://brage.bibsys.no/xmlui/handle/11250/168911

Takáts, E., \& Tumbarello, P. (2009). Australian Bank and Corporate Sector Vulnerabilities: An International Perspective. International Monetary Fund.

Tschemernjak, R. (2004). Assessing the regulatory impact: credit risk - going beyond Basel II. Journal of Risk Finance, 5(3), 10-13. https://doi.org/10.1108/09657960410699676

Van den Berghe, L. (2012). International standardisation of good corporate governance: best practices for the board of directors. Springer Science \& Business Media.

Van den Heuvel, S. J. (2002). Does Bank Capital Matter for Monetary Transmission ? Economic Policy Review, 8(1), 259-265.

Ward, A., Rodriguez, J., \& Dan, B. (2009). Governance bundles, firm performance, and the substitutability and complementarily of governance mechanisms. Corporate Governance: An International Review, 17(3), 646-660.

Weisbach, M. I. (1988). Outside Directors and CEO Turnover. Journal of Financial Economic, 20, 431460. https://doi.org/10.1061/(ASCE)CC.1943-5614.0000381

Wiersema, M., \& Bantel, K. (1992). Top Management Team Demography and Corporate Strategic Chang. Academy of Management Journal, 35, 91-121.

Willett, A. H. (1951). The economic theory of risk and insurance. New York: The Columbia University Press.

Xie, B., Davidson, W. I., \& DaDalt, P. J. (2003). Earnings management and corporate governance: the role of the board and the audit committee. Journal of Corporate Finance, 9(3), 295-316.

Zehri, F., \& Mbarek, B. N. (2016). Banks Performance in KSA during Financial Distress: A Comparative Study Islamic and Conventional Banks. Arabian Journal of Business and Management Review.

Zelenyuk, V., \& Zheka, V. (2006). Corporate Governance and Firm's Efficiency: The Case of a Transitional Country. Ukraine. Journal of Productivity Analysis, 25(1-2), 143-157.

Zhou, Q. (2011). Applied Economics, Business and Development: International Symposium, ISAEBD 2011, Dalian, China, August 6-7, 2011, Proceedings, Part 1. Springer.

Zicchino, L. (2005). A model of bank capital, lending and the macroeconomy: Basel I versus basel II. Bank of England, Financial Industry and Regulation Division, 74(SUPPL. 1), 50-77. https://doi.org/10.1111/j.1467-9957.2006.00517.x 